\title{
Gender and Perception of Profession
}

\author{
Fatma Ünal $^{1}$, Sinem Tarhan ${ }^{1}$, Eda Çürükvelioğlu Köksal ${ }^{1}$ \\ ${ }^{1}$ Faculty of Education, Bartin University, Bartin, Turkey \\ Correspondence: Fatma Ünal, Faculty of Education, Bartin University, Bartin, KutlubeyYazıcılar Campus, Turkey.
}

Received: January 14, 2018

doi:10.11114/jets.v6i3a.3156

\author{
Accepted: February 5, $2018 \quad$ Online Published: April 1, 2018
}

URL: https://doi.org/10.11114/jets.v6i3a.3156

\begin{abstract}
There are negative impacts of gender stereotypes particularly on the education of girls and women. The purpose of this study is to examine pre-service teachers' profession perceptions within the context of gender using word association test technique and to identify the definition of the concept of "profession" depending on sex. This study is designed as a qualitative research and involves 250 pre-service teachers. In analysing the data, descriptive analysis method is used. Findings are presented in frequency tables and concept networks. The results show that the first profession pre-service teachers mention in their sentences about the concepts of "women and profession" is "teacher", whereas it is "worker" for the concept of "men and profession". In the light of the findings, suggestions are made to overcome gender stereotypes and to help individuals to become aware of the acts and talks that reproduce gender inequality.
\end{abstract}

Keywords: gender, choosing profession, word association test

\section{Introduction}

Freedom of choice is one of the primary rights of individuals in democratic societies. Individuals having this freedom make decisions on many issues throughout their lifetime. Of all these decisions, the most important one is choosing a profession which will shape their lifestyle in the future (Kuzgun, 2001). According to Herr, Cramer and Niles (2004) "profession is the collection of activities based on knowledge and skills people acquire through education and carry out to earn their life. The rules of profession are set by the society" (cited in Yeşilyaprak, 2012). Choosing a profession is evaluating the different features of professions open to an individual and then deciding to choose the one which has more advantages and less disadvantages in terms of an individual's expectations (Tarhan, Çetin Gündüz and Kıliç, 2014). In addition to meeting physiological needs by earning money, having a profession fulfills such needs as developing the potential through finding the appropriate area for oneself to work, enabling psychological satisfaction and getting a social identity (Kuzgun, 2001; Yeşilyaprak, 2012).

The idea of having a profession starts to form around 5 years old. One of the main questions adults ask to children is "What will you be when you grow up?". As for Ginzberg, while children's answers to this question are totally imaginary at the beginning, as they grow up, get to know about themselves and recognize the realities of life, their answers become more conscious and realistic (Yeşilyaprak, 2012). One of the factors effecting the choice of profession is sex and the factor that is, in fact, effective in this sense is gender stereotypes (Moya, Expósito and Ruiz, 2010). When a girl's answer to "What will you be when you grow up?" is "astronout" and a boy's answer is "cook", they face such a reaction as "boys be astronout, you are a girl" or "cook is for girls, you should be engineer". The professions that society deems appropriate for men and women are shaped in a child's mind (Tarhan, Çetin Gündüz and Kılıç, 2014). Thus, cognitive and physical capacity, interests, values and dreams, which are important factors in choosing a profession develop in line with gender stereotypes supported by families and educational systems.

Gender stereotypes are effective in girls' and boys' socialization process, in the language they use and their way of communication. Girls are taught to take care of the children and elderly, to be patient, to be open to communication and cooperation, emotional intensity and emotional control, handicrafts, tendermindedness and physical attraction, which are accepted to be women's characteristics. Similarly, boys are taught to have management skills, to be decisive and authoritarian, to have self-control, physical strength, to be rational, fearless, to take risks, to be reliable and technologically literate, which are considered as men's characteristics (Özkaplan, 2013). In time, these characteristics are integrated with professions and thus, professions are divided as women's and men's profession. Children and young people are guided to professions accordingly. Gender stereotypes are even effective in the process of education which is the first step of having a profession. The impact of gender stereotypes is not only seen in their access to basic education, 
but also in what type of education they will have and for how long; and to what extent they will fulfill the requirements of their profession. According to Moya, Expósito and Ruiz (2010), women and men focus on different professions and women are represented with a smaller rate in education programs, labor market and higher status occupations.

There are studies looking into the relationship between choosing a profession and sex. Some of them are as given: Perceptions towards the nursing profession (Eskimez, Öztunç, and Alparslan, 2008; Ünsal, Akalın and Y1lmaz, 2010 ; Kaya, Turan and Öztürk, 2011), the impact of sex and values on choosing a profession (Uyguç, 2003), factors effective in the faculty of medicine (Çiftçi Bülbül, Bayar Muluk, Çamur Duyan and Yılmaz, 2011), close relationships, gender and career salience stereotypes (Moya, Expósito and Ruiz, 2010), medical science and choosing a profession (Sanfey, Saalwachter-Schulman, Nyhof-Young Eidelson, Mann, 2006), gender, entrepreneurship and career choice (Thebaud, 2010). However, when the literature is reviewed, it is seen that there are no studies looking into the relationship between profession as a concept and sex.

This study is important as it reveals to what extent individuals are under the impact of gender stereotypes when choosing a profession, and to what extent they consider these professions appropriate for themselves or the opposite sex.

\section{Method}

\subsection{Research Design}

This study is a qualitative research. The reason behind choosing qualitative research is because the purpose is to examine the role of gender in pre-service teachers' perceptions of profession. The main characteristic of qualitative study is that it focuses on how individuals construct reality within their interaction with the social world. Here, the researcher tries to understand the meaning of phenomena by looking into the participants of the phenomena (Merriam, 2013 , 22). In the current study, the professions and stereotypes of the participants on the concepts of "women and profession" and "men and profession" are examined based on their sex.

\subsection{Study Group}

In determining the study group, criterion sampling, one of the purposeful sampling methods, was used. Accordingly, the criteria used in this study were to be a pre-service teacher at Bartın University Faculty of Education during 2015-2016 academic years and to be voluntary. The study group involved 250 pre-service teachers of whom 163 were female and 87 were male.

\subsection{Data Collection Instruments and Implementation}

Word association test was used to collect the data in the study. Word association test is one of the most widely used techniques to analyze the cognitive structure of individuals and networks within this structure, in other words, the knowledge network among these concepts, and to determine if the connections between the concepts in the long-term memory are sufficient (Hovardas and Korfiatis, 2006). This technique is based on the hypothesis of answering a question without limiting the ideas and by only independently associating with the stimulant word (Sato and James, 1999). Data collection instrument used in this study involved two sections. The first section involved participants' sex. The second section involved "women and profession" and "men and profession" concepts. These concepts were given as the stimulant words for them to complete word association test and they were asked to write a sentence for each concept. After official permissions were taken, the test was administered by the researchers to the participants. Administration of the test lasted two minutes.

\subsection{Analysis of Data}

In analyzing the data descriptive analysis method was used. The main purpose in descriptive analysis is presenting the findings in an organized and interpreted way for the reader (Yıldırım and Şimşek, 2016, 239). The data collected using word association test were analyzed using the number of words, number of answers and semantic relationship technique (Atasoy, 2004). The classification is made based on the most frequently repeated words. The words that are irrelevant and have no relationships with other words were not counted. The words were categorized using semantic relationship criteria and their frequency was calculated (Kostova and Radoynovska, 2010). The findings are presented in tables and concept networks according to the category and category frequency. In the study, answers of the participants are grouped in seperate frequency tables based on gender and sample sentences are given and interpreted in these tables. Women participants are coded as $\mathrm{W} 1, \mathrm{~W} 2 \ldots$ and men participants are coded as M1, M2,... To ensure the reliability of the analysis, all data were coded by each researcher. $70 \%$ consensus is necessary for the reliability of the study (Yıldırım and Şimşek, 2016, 233). To ensure the reliability, the codes of both researchers and the categories related to the codes were compared to see if these codes represent the conceptual categories reached in the study. The reliability of the data analysis were calculated using [consensus/(consensus + dissensus) x 100] formula (Miles and Huberman, 1994). $98 \%$ consensus was reached among the researchers, who carried out the coding in this study. The main reason of this 
high consensus is that the answers of the participants (the professions they wrote) were very clear and these answers were directly used as categories. To ensure the validity of the study, all the analyzed data were subjected to an in-depth analysis.

\section{Results}

This section involves findings on pre-service teachers' answers to "women and profession" and "men and profession" concepts.

\subsection{Findings related to Women and Profession Concepts}

The concept network showing the answers of pre-service teachers on professions when "women and profession" are considered together are given in Figure 1.

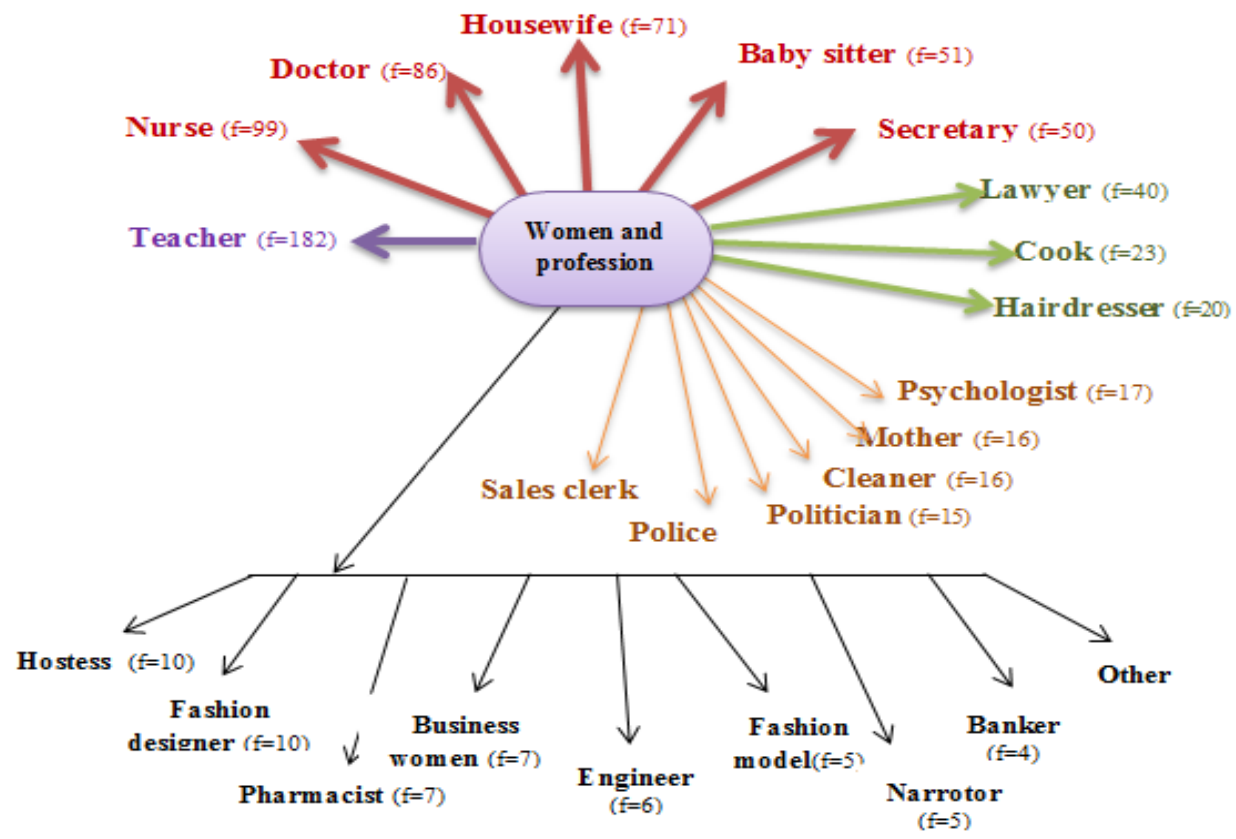

Figure 1. Women and the concept of profession

As it is seen in Figure 1 above, when the concepts of women and profession are considered together, the most highly associated profession among pre-service teachers is teacher (182). It is followed by nurse (99), doctor (86), housewife (71), baby sitter (51), secretary (50), lawyer (40), cook (23), hairdresser (20), psychologist (17), mother (16), cleaner (16), politician (15), police (11), sales clerk (11), hostess (10), fashion designer (10), pharmacist (7), business women (7), engineer (6), fashion model (5), narrator (5), banker (4) and other (14).

\subsection{Findings Related to Men and Profession Concepts}

The concept network showing the answers of pre-service teachers on professions when "men and profession" are considered together are given in Figure 2.

As it is seen in Figure 2, when the concepts of men and profession are considered together, the most highly associated profession to man among pre-service teachers is worker (94). It is followed by "they men do everything" (84), doctor (71), police (69), engineer (65), teacher (65), craftsman (55), driver (46), manager (43), sportsman (36), judge/prosecutor (33), politician (22), lawyer (21), academic (18), farmer (15), soldier (13), imam (11), businessman (11), architect (9), banker (8), civil servant (7), pilot (7), cook (6), mine worker (4) and other (5). 


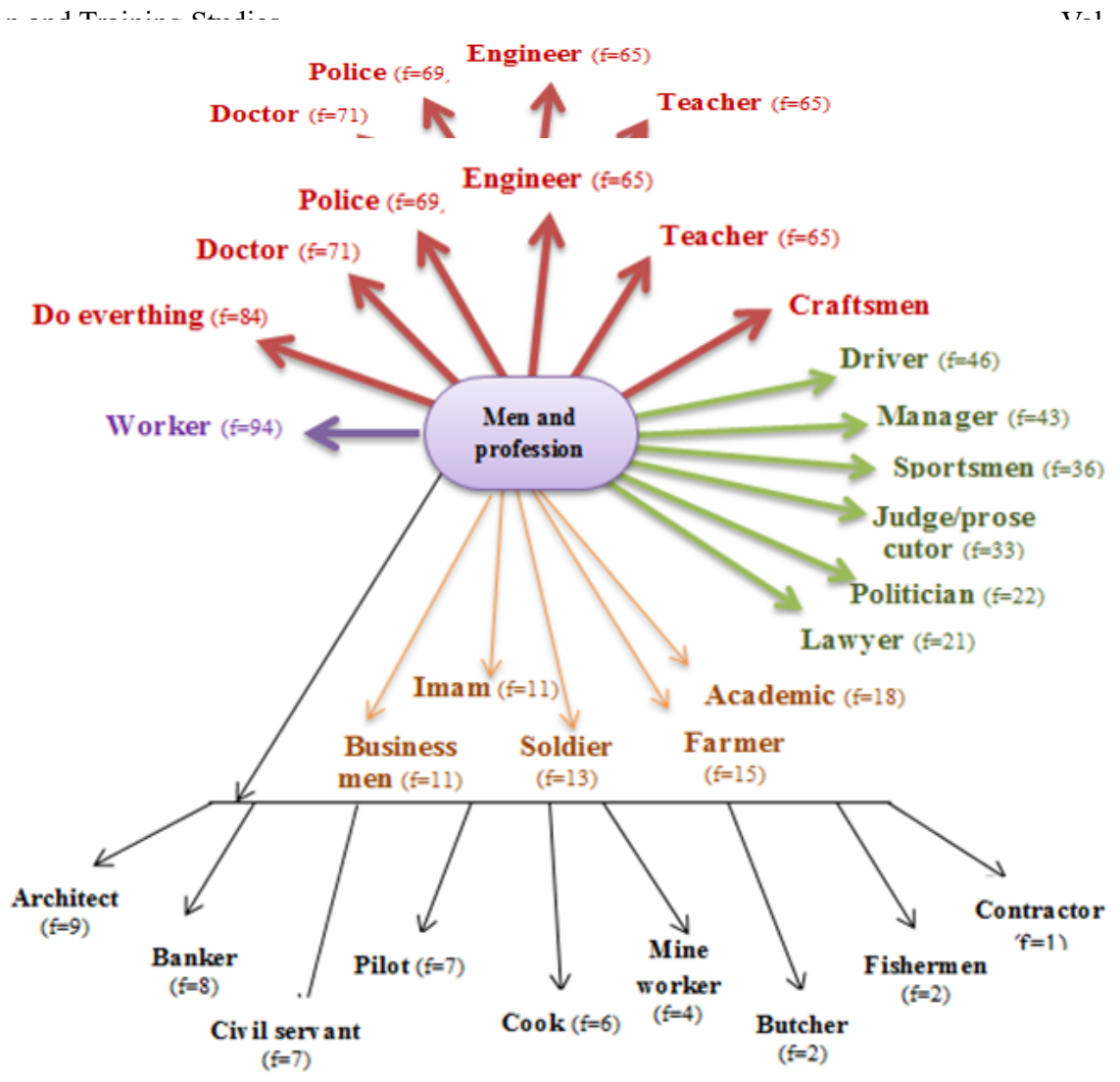

Figure 2. Men and the concept of profession 


\subsection{Findings on Women and Profession Concepts Based on Gender}

The breakdown of the categories of pre-service teachers' answers to women and profession concepts based on gender are shown in Table 3.

Table 3. The breakdown of answers towards women and profession concepts based on gender

\begin{tabular}{|c|c|c|c|}
\hline Sex & Profession category & $\begin{array}{l}\text { Category } \\
\text { Frequency }\end{array}$ & Sample sentence \\
\hline \multirow[t]{17}{*}{ Women } & Teacher & 118 & - "The most suitable job for women is teaching."”' (W9) \\
\hline & Nurse & 60 & $\begin{array}{l}\text { - "Teaching, nursing, being a civil servant and secretary are perfectly suitable } \\
\text { jobs for women." (W147) }\end{array}$ \\
\hline & Doctor & 53 & $\begin{array}{l}\text { - "When women go to see a doctor, they prefer women doctors for their privacy." } \\
\text { (W192) }\end{array}$ \\
\hline & Baby sitter & 43 & $\begin{array}{l}\text { - "Some women prefer to be housewife while others choose some other } \\
\text { professions. They choose child care, teaching or kindergarten teaching." (W24) }\end{array}$ \\
\hline & Housewife & 41 & $\begin{array}{l}\text { "Women do most of the work at home in their daily lives. However, when it } \\
\text { comes to specializing in a specific area, than you hear the screams of "you can } \\
\text { not do that". The most important occupation of a woman is being a housewife, } \\
\text { she is the one who makes home."(W22) }\end{array}$ \\
\hline & Secretary & 31 & $\begin{array}{l}\text { - "Women generally do not get sufficient education. They do such low-level jobs } \\
\text { as secretary and civil servant." (W45) }\end{array}$ \\
\hline & Lawyer & 29 & $\begin{array}{l}\text { - "Women mostly have verbal intelligence. They prefer jobs that they can be } \\
\text { comfortable in their lives which do not require extra working hours such as } \\
\text { being a lawyer." (W2). }\end{array}$ \\
\hline & Cook & 17 & - "Woman is the best cook." (W159) \\
\hline & Hairdresser & 15 & $\begin{array}{l}\text { - "Women are tender, their sense of aesthetics is developed. They do such jobs as } \\
\text { hairdresser and beauty expert well." (W128) }\end{array}$ \\
\hline & Psychologist & 11 & $\begin{array}{l}\text { - "Women prefer professions where they can use their emotional role due to their } \\
\text { nature." (W139) }\end{array}$ \\
\hline & Cleaner & 11 & $\begin{array}{l}\text { - "Women are always housewifes. As they can not go to school, they do cleaning } \\
\text { and baby sitting to financially support home." (W95) }\end{array}$ \\
\hline & Politician & 8 & $\begin{array}{l}\text { - "Women are more emotional, they are also reliable and handle things. I think at } \\
\text { least half of the parliamentarians should be women. We will better make our } \\
\text { voice heard." (W28) }\end{array}$ \\
\hline & Engineer & 6 & $\begin{array}{l}\text { - "Because women are tender, they are not approved when they choose such jobs } \\
\text { as engineering. I believe women can be great engineers. They think more } \\
\text { meticulously." (W202) }\end{array}$ \\
\hline & Police & 6 & $\begin{array}{l}\text { - "The number of women police, soldiers, security staff should be increased." } \\
\text { (W89) }\end{array}$ \\
\hline & Pharmacist & 5 & $\begin{array}{l}\text {-Women should choose jobs in which they will spend less time out and more } \\
\text { time at home with their kids- such as being a pharmacist." (W236) }\end{array}$ \\
\hline & Fashion model & 5 & - "Fashion models are unfortunately seen from a sexist point of view." (K21) \\
\hline & Hostess & 3 & $\begin{array}{l}\text { - "Women are seen more appropriate for service related jobs such as being a } \\
\text { hostess." (W94) }\end{array}$ \\
\hline \multirow[t]{20}{*}{ Men } & Teacher & 64 & $\begin{array}{l}\text { - "The best job for a woman is teaching. Women's selection of profession is } \\
\text { limited." (M51) }\end{array}$ \\
\hline & Nurse & 39 & - "The best job women can do is nursing." (M66) \\
\hline & Doctor & 33 & - "Gynechologists should be women." (M52) \\
\hline & Housewife & 30 & - "Women's main job is to be housewife." (M79) \\
\hline & Secretary & 19 & - "Most women can not read and work in such jobs as secretary." (M49) \\
\hline & Mother & 16 & - "Women's most important job is being a mother." (M18) \\
\hline & Lawyer & 11 & $\begin{array}{l}\text { - "Women's social intelligence and communication skills are good and part-time } \\
\text { jobs are more appropriate for them such as being a lawyer." (M57) }\end{array}$ \\
\hline & Sales clerk & 11 & $\begin{array}{l}\text { - "Many women work at such jobs as being a sales clerk to support their house. } \\
\text { Many women do not get support from their family for their education." (M62) }\end{array}$ \\
\hline & Fashion design & 10 & - "Women are good fashion designers." (M75) \\
\hline & Baby sitter & 8 & - "With their mothering instinct, women can do baby sitting well." (M82) \\
\hline & Hostess & 7 & - "Being a hostess is a good job for women." (M47) \\
\hline & Business woman & 7 & $\begin{array}{l}\text { - "Women can have a career and be a mother as well. There are many business } \\
\text { women." (M73) }\end{array}$ \\
\hline & Politician & 7 & - "Women can be a step ahead of men in communicating." (M58) \\
\hline & Cook & 6 & - "Women are good mothers, housewifes and cooks." (M64) \\
\hline & Psychologist & 6 & $\begin{array}{l}\text { - "Women are great listeners. They could do such jobs as being a psychologist } \\
\text { and counselling well." (M12) }\end{array}$ \\
\hline & Cleaner & 5 & - "Women are mothers, baby sitters and cleaners for all their lives." (M71) \\
\hline & Hairdresser & 5 & $\begin{array}{l}\text { - "Women have great hand skills. They could do craftswork well. They can be } \\
\text { hairdresser." (M18) }\end{array}$ \\
\hline & Police & 5 & $\begin{array}{l}\text { - "Women are needed in security issues. Women should be police and soldiers." } \\
\text { (M27) }\end{array}$ \\
\hline & Banker & 3 & - "Women are very careful. Banking is a good job for them." (M36) \\
\hline & Director/ Manager & 3 & $\begin{array}{l}\text { - "Women work hard and they are determined. We see women managers more } \\
\text { now." (M32) }\end{array}$ \\
\hline
\end{tabular}


As it is seen in Table 3, on the top of the list female pre-service teachers make on the concepts of women and profession is being a teacher; and it is followed by nurse, doctor, baby sitter and housewife. These jobs are followed by secretary, lawyer, cook, hairdresser, psychologist, cleaner, politician, engineer, police, pharmacist, fashion model and hostess.

And in the list of male pre-service teachers on the concepts of women and profession, it is again being a teacher that is on top of the list. It is followed by nurse, doctor, housewife, secretary, mother, lawyer, sales clerk, fashion designer, baby sitter, hostess, business woman, politician, cook, psychologist, cleaner, hairdresser, police, banker and manager, in the given order.

\subsection{Findings on Men and Profession Concepts Based on Gender}

The breakdown of the categories of pre-service teachers' answers to men and profession concepts based on gender are shown in Table 4.

Table 4. The breakdown of answers towards men and profession concepts based on gender

\begin{tabular}{|c|c|c|c|}
\hline Sex & $\begin{array}{l}\text { Profession } \\
\text { category }\end{array}$ & $\begin{array}{l}\text { Category } \\
\text { Frequency }\end{array}$ & Sample sentence \\
\hline \multirow[t]{18}{*}{ Woman } & Worker & 53 & - "Men can easily do such jobs as worker as they are strong." (W43) \\
\hline & Police & 49 & - "We see that most of the police in the society is male." (W9) \\
\hline & Engineer & 45 & $\begin{array}{l}\text { - "Men's mathematical intelligence is better and they tend to do jobs that require } \\
\text { physical strength." (W4) }\end{array}$ \\
\hline & Do evernthing & 41 & $\begin{array}{l}\text { - "Men should have a job, as the people who bring money home. They do } \\
\text { anything." (W6) }\end{array}$ \\
\hline & Doctor & 39 & - "Male doctors are better in their job." (W40) \\
\hline & Craftsman & 31 & - "My father is a craftsman. Craftsmen are always male." (W211) \\
\hline & Director/Manager & 27 & $\begin{array}{l}\text { - "Men are thought to be better in management jobs. They do administrative jobs." } \\
\text { (W7) }\end{array}$ \\
\hline & Driver & 26 & - "Driving is seen as men's job." (W181) \\
\hline & Teacher & 25 & $\begin{array}{l}\text { - "Such jobs as teaching in which you use pen and paper are good for men." } \\
\text { (W54) }\end{array}$ \\
\hline & Judge/prosecutor & 21 & - "Judges and prosecutors are mostly men. They look tougher." (W82) \\
\hline & Sportsman & 18 & $\begin{array}{l}\text { - "Most men are interested in sports branches and most sportsmen in our country } \\
\text { are male." (W159) }\end{array}$ \\
\hline & Politician & 14 & - "Politicians are generally men. Women should also be given opportunity." (W98) \\
\hline & Lawyer & 12 & - "Confiscation lawyers are mostly men." (W206) \\
\hline & Academic & 10 & $\begin{array}{l}\text { - "Most academics in the universities are men. They are given more opportunities. } \\
\text { (W234) }\end{array}$ \\
\hline & Cook & 6 & - "Men from Bolu are good cooks." (W58) \\
\hline & Imam & 6 & - "All imams are men as this is required according to our religion." (W196) \\
\hline & Civil Servant & 6 & $\begin{array}{l}\text { - "There are men who prefer to be civil servant although the number is very low } \\
\text { compared to women. Everything is ok as long as it is a job!" (W64) }\end{array}$ \\
\hline & Pilot & 6 & $\begin{array}{l}\text { - "Pilots are always men. It is like courage and fearlessness is a man's thing." } \\
\text { (W56) }\end{array}$ \\
\hline \multirow[t]{18}{*}{ Man } & $\begin{array}{l}\text { Men do } \\
\text { everything }\end{array}$ & 42 & $\begin{array}{l}\text {-"They do anything. They do anything to bring Money to their home." } \\
\text { (M41) }\end{array}$ \\
\hline & Worker & 41 & -"Men do jobs that require strength. Workers are always men." (M32) \\
\hline & Teacher & 40 & - "Men mostly prefer to be high school teachers." (M49) \\
\hline & Doctor & 32 & - "Being a doctor is prestigious and profitable so it is preferred by men." (M85) \\
\hline & Craftsman & 24 & $\begin{array}{l}\text { - "Most men want to establish their own business. They do not want to work under } \\
\text { someone's authority. Craftsmen are mostly men." (M58) }\end{array}$ \\
\hline & Engineer & 20 & - "Engineering is mostly preferred and focused on by men."(M39) \\
\hline & Police & 20 & $\begin{array}{l}\text { - "Due to their tough nature, men do jobs that require toughness better. Such as } \\
\text { police, soldier, judge, prosecutor, etc." (M37) }\end{array}$ \\
\hline & Driver & 20 & - "Driving is a man's job." (M73) \\
\hline & Sportsman & 18 & $\begin{array}{l}\text { - "All men want to be a sportsman when they are child. They especially want to be } \\
\text { football players." (M35) }\end{array}$ \\
\hline & Director/manager & 16 & $\begin{array}{l}\text { - "Men not only can do jobs that require physical strength but also stand out in } \\
\text { management jobs." (M60) }\end{array}$ \\
\hline & Farmer & 15 & - "Men living in the villages are mostly farmers." (E69) \\
\hline & Soldier & 13 & - "Men should always be soldiers. Being a soldier is for men."(M52) \\
\hline & Judge/prosecutor & 12 & $\begin{array}{l}\text { - "Men are not emotional like women. They do such jobs as prosecutors better." } \\
\text { (M22) }\end{array}$ \\
\hline & Businessman & 11 & $\begin{array}{l}\text { - "All men want to be an important businessman. Holding owners are always men. } \\
\text { Men have more entrepreneurial spirit and are fearless."(M69) }\end{array}$ \\
\hline & Lawyer & 9 & \\
\hline & Academic & 8 & - "Most scientists are men. So are academics." (M38) \\
\hline & Politician & 8 & $\begin{array}{l}\text { - "It is seen that men are engaged more in politics than women." } \\
\text { (W77) }\end{array}$ \\
\hline & Imam & 5 & - "Imam has to be man." (E43) \\
\hline
\end{tabular}


As it is seen in Table 4, on the top of the list female pre-service teachers make on the concepts of men and profession is being a worker; and it is followed by police, engineer, do everything and doctor in the given order. These jobs are followed by craftsman, director/manager, driver, judge/prosecutor, sportsman, politician, lawyer, academic, cook, imam, civil servant, architect and pilot.

And in the list of male pre-service teachers on the concepts of men and profession, it is "do everything" that is on top of the list. It is followed by worker, teacher, doctor and craftsman. These jobs are then, followed by engineer, police, driver, sportsman, director/manager, farmer, soldier, judge/prosecutor, businessman, lawyer, academic, politician and imam.

\section{Discussion}

The results of the study show that professions that require university education among professions female pre-service teachers consider appropriate for women are teacher, nurse, doctor, lawyer, psychologist, engineer, pharmacist and architect. The impact of gender stereotypes in choosing these professions is obvious. Teaching, in particular, pre-school teaching is considered to be related to the education and care of the children at home and at school; and nursing is considered appropriate for women as it is related to care. Profession of a doctor represents a conservative point of view rather than knowledge, skills and tendency of women. This is indicated in such example sentences of the students as "women's privacy and gynecologists are women". The professions of lawyers and pharmacists are seen as jobs that do not require full-time work and enable women to take care of their home. Gender stereotypes are emphasized in the professions of engineers and architects. However, the idea that these professions are appropriate for women is explained by women's detailed thinking and that these professions put aesthetic to the forefront. Being a psychologist, hairdresser and acting are also considered appropriate for women due to their emotional dimension and the importance attached to aesthetic values. In this study, politics is seen as a tool for "making one's voice heard" by female pre-service teachers. Y1lmaz, Zeyneloğlu, Kocagöz, Kısa, Taşkın and Eroğlu (2009) indicated in their study that women should have a more active role in politics.

Female participants explained the profession of cooking by indicating that women are good at cooking, the profession of hostess by indicating that women are appropriate for service jobs are clear indications of their embracing gender stereotypes. There are participants who consider being a narrator an appropriate job for women since most of the narrators are women. Female participants think that the reason women have such jobs as secretary and cleaner, which can be done with a lower level of education, is because women do not receive education and those jobs which require extra working hours are not considered appropriate for women. Being a housewife is considered as a profession and seen as the basic duty of women.

The findings of this study are consistent with the findings in the literature. In their study, Çiftçi Bülbül, Bayar Muluk, Çamur Duyan and Yilmaz (2011) found that majority of female students prefer nursing, physiotherapy, rehabilitation and child development, which are considered "professions for women". In their study, Eskimez et al. (2008) found that the professions students consider ideal for women are teacher, doctor, nurse and lawyer. Although being a lawyer is considered as an appropriate job for women, the number of female bar presidents in Turkey is very small. Similarly, the number of women in high positions as judge and prosecutor professions is very limited. Prosecutors are obliged to work in less developed regions in Turkey for some time. In addition, they work without a restriction of place and time while doing their job. Therefore, this job is preferred less by women (Kalem Berk, 2013). Seron (1997) found that woman lawyers give up their passions for their profession due to their roles as mother and housewife; and female lawyers prefer to work in public institutions or as freelancers instead of working in private sector (cited in Kalem Berk, 2013). Families make their female children to choose part-time work or jobs that do not require specialization and thus, make them spare time for their husband and children. Thus, the role of the women in the society and in the family; and the limits of her efforts in business life are established (Erol, 2011). According to Kiren Gürler and Üçdoğruk (2007), as women's level of education increases, so does the rate of participation to labor forces. On the other hand, being married effects women's participation to labor market negatively. Besides, Theabum (2010) indicates that sex is an important factor in choosing profession and in entrepreneurship; and women consider themselves less entrepreneur.

When the professions male pre-service teachers consider appropriate for women are examined, it is teacher, nurse, doctor and lawyer that are on the top of the list. These professions show that from a man's point of view, it is the educator, caregiver and in-house roles of women that stand out while choosing a profession. Although the duration of education and the working conditions of doctors is difficult, this profession is considered appropriate for women, in particular gynecological diseases and birth. In their study, Yılmaz, Zeyneloğlu, Kocagöz, Kısa, Taşkın and Eroğlu (2009) found that the opinions of male students towards the working life of women supports gender discrimination.

Most men in Turkey still think and behave within the framework of gender stereotypes. Therefore, the fact that male participants in the study consider being a businesswoman and politician appropriate for women is important as it shows the development in the mentality. Women exist in three different levels in the labor market: horizontal separation which represents women and men working in different business branches and businesses (e.g. women working mostly in the service sector), vertical separation which represents women and men working in the same business but in different 
positions (for example, managers are man) and contract-based separation (e.g. women work in part-time jobs, men work in full-time jobs) (Y1ldı, 2008; Parlaktuna, 2010). According to TUSIAD (Turkish Industrialists' and Businessmen's Association) Woman-Man Equality Working Group's survey on "Women in Business Life" 10,3\% president of the boards are women in private companies and $13 \%$ of the general managers are women (TCÇGR, 2013). Although their numbers are very small, that business women and women politicians are mentioned in print and visual media could be because men consider these professions appropriate for women. Although there are 27 ministers in the government in 2016, only one of them is woman. In Zeyneloğlu et al.'s (2009) study $26,4 \%$ of the male students participating in the study considered politics as a man's job. However, today, the view that politics is appropriate for women can be interpreted as the acceptance of the idea that politics can be done by women. As for Hacığlu Deniz and Haykır Hobikoğlu (2012), such criteria as the number of woman parliamentarians, ministers, woman managers, woman Professional and technical staff show the efficiency of women in administration. Whilst the rate of woman mayors in 2009 local elections in Turkey was $0,9 \%$, this rate increased up to $2,9 \%$ in 2009 local elections. The rate of woman mukhtar (local authority) in 2009 local elections was 2,3\% and the same rate was around 2\% in 2014 elections (TÜIK, 2016).

There are still girls who are prevented from going to school and taking education. Those girls can not have a job in their adult lives and can not work in qualified jobs. Therefore, male participants indicate that such jobs as being a secretary or sales clerk, which does require less education, are more appropriate for women. In Turkey, there is a viewpoint that sees boys as breadwinner of the family. Therefore, families having financial difficulties offer the educational opportunities for their sons for a better future and income. Also, this attitude is supported by the idea that girls will marry and will not provide financial support to their families then.

While female participants consider being a housewife as a job, male participants consider being a housewife and a mother as a job. This finding is consistent with the findings in the literature. In his research, Balkır (1989) found that when the term "successful woman" is mentioned, what comes to mind is a "good wife" and a "good mother" and from the viewpoint of men, for a woman to be successful, it is necessary to fulfill such traditional roles as being a good wife, a good housewife and a good mother (Kuzgun and Sevim, 2004). Male pre-service teachers considered being a fashion designer, hostess, psychologist and banker appropriate for women as their aesthetic values are high, they are open to communication, careful and hardworking. Male pre-service teachers believe women could be directors and they indicate this by saying: "now that, we see woman directors". Women's inclination towards "jobs that look naturally man-job" and their being visible in the society is important for them to be accepted as member of profession. Male participants see cleaner, cook, baby sitter and hairdresser jobs as natural jobs of women.

On top of the list that female pre-service teachers consider appropriate for men is "worker" and it is followed by police, engineer, "men do everything" and doctor in the given order. These jobs are followed by craftsman, director/manager, driver, teacher, judge/prosecutor, sportsman, politican, lawyer, academic, cook, imam, civil servant, architect, pilot and banker. The impact of gender stereotypes is seen in this listing. Female participants emphasize the physical strength of men and indicate that they can work in hard labor. Although many jobs can be done by machines or on computer in today's world, defining jobs based on the physical strength of men reveals that women are under the impact of gender stereotypes towards men. It is mostly men who work as police and lawyer. Judges and prosecutors are expected to have a tough, decisive look and not to reveal their emotions and these characteristics are considered to be unique to men. In engineering men are considered to be appropriate for the job as it requires physical strength as well as cognitive skills. Female pre-service teachers indicated that being a craftsman is something appropriate for men as their fathers or some of their family members are craftsman. Managing is considered to be a man's skill and men's management is accepted in many fields. Female pre-service teachers see being a sportsman as a man's thing and this has something to do with the fact that when the word "sports" is mentioned, what comes to mind in our society is football and football players are men. That men are seen as religious officials has something to do with the religious rules.

On the top of the list that male pre-service teachers consider appropriate for men is "men do everything". It is followed by worker, teacher, doctor and craftsman, engineer, police, driver, sportsman, director/manager, farmer, soldier, judge/prosecutor, businessman, lawyer, academic, politician, imam, banker, mine worker and architect in the given order.

The expression "men do everything" is an indication showing that for both women and men, it is still a man's responsibility to take care of the home. In Turkish society, for a man to marry, he has to work and earn money. This expression indicates that opportunities for men to find a job and choose a profession are still wider. Male pre-service teachers also explain "men do everything" expression as an indication that men are wise, skilled and adequate in everything (for instance, men have the capacity to do any job).

Being a worker is associated with physical strength and men's physical strength is brought into forefront. Being a craftsman in Turkish society is unique to men and transferred from father to son. This enables the transfer of an existing economic power to men, on the one hand, and enables them to work independently, on the other hand. Being a doctor is considered to be 
appropriate for men as it provides respect and high income. Being a teacher is considered appropriate for women especially in pre-school and primary school but for high school, it is men who are considered appropriate as high school teachers. The dominating view here is that the authoritarian attitudes of men should be used to control the students who are in puberty during this period. While being a teacher is associated with the concepts of care, love, education for women it is associated with authority, control and power for men. Similarly, such characteristics of men as their physical strength, tough, authoritarian, decisive attitudes etc. are attributed to being engineer, police, judge/prosecutor, businessman, politician as it is mostly men doing these jobs. According to Özkaplan (2013), men are expected to be competitive, demanding, aggressive, decisive, independent, logical, speak well and hide their feelings. This creates invisible obstacles for women in business life.

In Turkey, there are jobs that women are prohibited from doing through laws. One of those jobs is mining. According to the $72^{\text {nd }}$ article of the Labor Law no 4857: "Women, irrespective of their age, must not be employed on underground or underwater work like in mines, cable-laying and the construction of sewers and tunnels." (ÇSGB, 2017). Therefore, it is natural that male participants see mining as a man's job.

To sum up, human capital is one of the most important sources of development of countries. Using human capital effectively depends on conscious choice of professions. Beyond gender stereotypes, choosing a profession should be in line with the interests, skills, physical and mental capacity, values and dreams of individuals. In particular, women's participation in business life not only improves economic development but also effects women's status within the society and family positively; and contributes to the social and cultural development of the country (Parlaktuna, 2010).

The visibility of role models and professionals is highly important in choosing a profession. In their study, Sanfey et al. (2006) indicate the importance of role models behind girls' choice to study medicine. In their study they carried out with girls-at-risk, Tekin Karagöz and Mamur (2015) found that participants' perception of professions concentrated on being a housewife and that the professions participants want to choose in the future centered on being a teacher, police and sportsman which they see often in their environment. Accordingly, it can be said that increasing the number of woman role models doing different jobs in the society will help to overcome gender stereotypes.

Although gender stereotypes affect mainly women, it affects the life and choices of both sexes and causes to discrimination. The results of this study indicate that men are under the impact of gender stereotypes while choosing a profession (being physically strong, earning money for the household, etc.). Therefore, individuals should be educated on gender equality starting from an early age. Individuals around children they interact with (family members, playmates, teachers, characters they see on television and books, etc.) could be role models that a child can observe and imitate (Dökmen, 2004). In her study Esen (2013) offered a short systematic education to university students on gender and when students were asked about their values of judgement at the end of the education, she found that they had a motivation for change and observed a motivation for change in their own lives. In addition, it was seen that gender education could create new awareness and sensitivity in the participants or enabled them to support their existing awareness and sensitivity with a conceptual framework. Therefore, since teachers are important role models for their students, they should be aware of gender stereotypes. It is important to organize trainings that will create awareness on gender equality for both teachers and pre-service teachers.

\section{References}

Atasoy, B. (2004). Learning and Teaching Science. Ankara: Asil.

Çiftçi, G. E., Bülbül, S. F., Bayar, M. N., Çamur, D. G., \& Yılmaz, A. (2011). Factors in selecting a university and career among students studying in the faculty of health sciences (Kirikkale University). J. Kartal. T. R., 22(3), 151-160. https://doi.org/10.5505/jkartaltr.2011.98704

Dökmen, Z. Y. (2004). Gender: Social psychological explanations. İstanbul: Sistem.

Erol, A. (2011). Gender based discrimination in business life; European union and Turkey. Unpublished Master Thesis, Trakya University.

Esen, Y. (2013). A study for developing gender sensitivity in pre-service teacher education. Education and Science, 38(169), 280-295.

Eskimez, Z., Öztunç, G., \& Alparslan, N. (2008). Opinions of last year high school girls about nursing. Hacettepe University Faculty of Health Sciences Nursing Journal, 58-67.

Hacıoğlu, D. M., \& Haykır, H. E. (2012). Economic evaluation of women employment in the context of development index according to gender: Case of Turkey. International Conference on Eurasian Economies: Session 1b, 123-130.

Hovardas, T., \& Korfiatis, K. J. (2006). Word associations as a tool for assessing conceptual change in science education. Learning and Instruction, 16, 416-432. https://doi.org/10.1016/j.learninstruc.2006.09.003 
Kalem, B. S. (2013). Gender and professionalization: The example of women in the legal profession. Journal of Sociological Research, 16(1), 75-103.

Kaya, N., Turan, N., \& Öztürk, A. (2011). Men nurse image in Turkey. International Journal of Human Sciences, 8(1), 16-30.

Kiren, G. Ö., \& Üçdoğruk, Ş. (2007). Applying prohibit analysis to income differences in Turkey regarding gender. Journal of Yasar University, 2(6), 571-589.

Kostova, Z., \& Radoynovska, B. (2010). Motivating students' learning using word association test \& concept maps. Bulgarian Journal of Science and Education Policy, 4(1), 62-98.

Kuzgun, Y. (2001 ). Career choice- The most important decision of modern people. Bilim ve Teknik, 50-54. Retrieved from: http://vizyon21yy.com/documan/egitim_ogretim/rehberlik/mesleki_tanitim/Meslek_Secimi.pdf

Kuzgun, Y., \& Sevim, S. (2004). The relationship between attitudes towards women's work roles and religious tendency. Ankara University, Journal of Faculty of Educational Sciences, 37(1), 14-27.

Merriam, S. B. (2013). Qualitative research: A guide to design and implementation. (S. Turan, Çev.). Ankara: Nobel.

Miles, M. B., \& Huberman, A. M. (1994). Qualitative data analysis: An expanded sourcebook (2nd ed.). Thousand Oaks, California: SAGE.

Moya, M., Expósito, F., \& Ruiz, J. (2010). Close relationships, gender, and career salience. Sex Roles, 42(9-10), $825-846$.

Özkaplan, N. (2013). Women academicians: Glass ceilings are still too thick!. KADEM Journal of Women's Studies, $1(12), 1-23$.

Parlaktuna, İ. (2010). Analysis of gender-based occupational discrimination in Turkey. Ege Academic Review, 10(4), 1217-1230.

Sanfey, H. A., Saalwachter-Schulman, A. R., Nyhof-Young, J. M., Eidelson, B., \& Mann, D. (2006). Influences on medical student career choice. Arch Surg, 141, 1086-1095. https://doi.org/10.1001/archsurg.141.11.1086

Sato, M., \& James, P. (1999). "Nature" and "Environment" as perceived by university students and their supervisors. International Journal of Environmental Education and Information, 18(2), 165-172.

Tarhan, S., Çetin, G. H., \& Kılıç, Z. (2014). Cinsiyet Kalıp Yargılarının Aşılmasında Psikolojik Danışma ve Rehberlik Hizmetleri. S. Doğan (Edt.) Benim Madam Curie'm Eğitici El Kitabı. Ankara: MG Yapım, Ajans, Halkla İlişkiler. Retrieved from: d284f45nftegze.cloudfront.net/AliUzman/madam_curieM_kitapcik_web_V2.pdf

TCÇGR (2013). T.C. Kalkınma Bakanlığı Onuncu Kalkınma Planı Toplumsal Cinsiyet Çalışma Grubu Raporu. Retrieved from: kasaum.ankara.edu.tr/.../Toplumsal-Cinsiyet-Çalışma-Raporu-2013Basılacak-Nüsha.pdf

Tekin, K. C., \& Mamur, N. (2015). The reflections of girls at risk about their future and profession perceptions to their drawings. Journal of Qualitative Research in Education, 3(1), 26-53.

Thebaud, S. (2010). Gender and entrepreneurship as a career choice do self-assessments of ability matter?. Social Psychology Quarterly, 73(3), 288-304. https://doi.org/10.1177/0190272510377882

TÜIK (2016). Turkish Statistics Institute. Women with statistics. Retrieved from: http://www.tuik.gov.tr/HbPrint.do?id=24643

Ünsal, A., Akalın, İ., \& Yılmaz, V. (2010). Opinions of different profession working people related men nurse. International Journal of Human Sciences, 7(1), 420-431.

Uyguç, N. (2003). Gender, personal values and choice of profession. D.E.Ü.I.I.B.F Journal, 18(1), 93-103.

Yıldırım, A., \& Şimşek, H. (2016). Qualitative reserach methods in socia sciences (10th ed.). Ankara: Seçkin.

Yıldız, G. B. (2008). İşverenin eşit işlem yapma borcu. Ankara: Yetkin.

Yılmaz, D. V., Zeyneloğlu, S., Kocaöz, S., Kısa, S., Taşkın, L., \& Eroğlu, K. (2009). Views on gender roles of university students. International Journal of Human Sciences, 6(1), 775-792.

\section{Copyrights}

Copyright for this article is retained by the author(s), with first publication rights granted to the journal.

This is an open-access article distributed under the terms and conditions of the Creative Commons Attribution license which permits unrestricted use, distribution, and reproduction in any medium, provided the original work is properly cited. 